\title{
Physicians in opera-reflection of medical history and public perception
}

\author{
Stefan N Willich
}

\section{Introduction}

Music plays an increasingly important part in medicine, such as in specific care for performing artists. ${ }^{1}$ But what about the representation of medicine in music?

A systematic search in theatrical reference books yielded 40 operas from three centuries in which physicians appear on stage (see table on bmj.com). I selected several operas as specific examples in the history of opera. I analysed the role and function of the physician in different categories including the character and importance of his role, his function and basis of knowledge, and his social status. I also looked at the historical context.

\section{Eighteenth century}

Opera developed in the late Renaissance and early Baroque. $^{2}$ There are no doctors in the operas of Monteverdi, Gluck, or Handel, partly because the stories are often based on material from mythology or antiquity. In the 18th century, however, our colleagues enter the stage.

In Doktor und Apotheker (Doctor and Pharmacist, 1786) by Carl Ditters von Dittersdorf, the physician Dr Krautmann extols his importance in the introductory aria. The satirical way in which this is done leaves doubt as to his real reputation. Dr Krautmann's son and the pharmacist Stoessel's daughter are in love with each other. When Stoessel finds this out, he tries to marry his daughter off to an old friend. The young lovers try to prevent this with a masquerade. The plan fails initially, and all the while the two opponents clash violently time and again, each questioning the other's professional competence and threatening to take legal action. The conflict was predetermined because of overlapping areas of professional competence. The composer uses this issue as a creative element, and the physician appears in his professional role albeit in a grotesque manner.

\section{Nineteenth century}

Romanticism revived old mythological subjects such as the story of Tristan and Isolde, whose central theme is a potion inducing irresistible love. ${ }^{3}$ In Donizetti's L'Elisir d'Amore (The Love Potion, 1832) the peasant Nemorino is in love with the wealthy lady Adina, who in turn is enamoured with the military and flirts with Sergeant Belcore. When the travelling physician Dr Dulcamara comes into town, Nemorino asks him for a love potion. The doctor sells him a bottle of Bordeaux wine. As he drinks more wine, Nemorino grows surer of himself and dances with the village girls. Dr Dulcamara obviously relies here on the disinhibiting effect of alcohol. Nemorino's behaviour makes Adina jealous, and she actually falls in love with him. The two marry and subsequently Nemorino inherits a consider- able fortune. Dr Dulcamara exploits this opportunity to enhance his fame by claiming that the sudden wealth is also due to the medication.

Dr Dulcamara is one of the first physicians as a leading character in opera and reflects the situation of medicine in the early 19 th century. ${ }^{4}$ Some ideas still prevailed that dated back to antiquity and were based on Galen's humoralism. Humoral pathology was closely related to a holistic therapy (as the one proposed by Dulcamara) and was displaced in the course of the century by the development of cellular pathology and associated new medical methods. Virchow, Pasteur, Koch, Mendel, Charcot, and their colleagues represent the era in which medicine is placed on modern scientific foundations.

In the 19th century, surgery was integrated into medicine. In Verdi's opera La Forza del Destino (The Force of Destiny, 1862), a surgeon is of great importance for the plot. ${ }^{5}$ He removes a bullet from the chest of Don Alvaro, who survives the procedure-only to die caught up in a web of tragic entanglements. Donizetti's opera Don Pasquale (1843) portrays the increasing power of the physician to exercise psychological influence. ${ }^{6}$ In this opera Dr Malatesta (Dr Headache) gets Norina to agree to a sham marriage with the old Don Pasquale.

One of the best known tragic operas of the 19th century is Verdi's La Traviata (1853). Alfredo, who comes from a good home, falls in love with Violetta, a star of the Parisian demi-monde. His father, fearing for the family name, asks Violetta to leave his son. She acquiesces without giving Alfredo the true reasons. The latter, mad with jealousy, exposes her as a prostitute. Subsequently, Violetta's health deteriorates rapidly, probably because of progressive tuberculosis. Dr Grenvil, her physician, supports her but predicts that she will soon die. At the end of the opera, he knows that he cannot save his patient and stays with her until she dies. The role of the physician is extended with sympathy and comfort.

Les Contes d'Hoffmann (Tales of Hoffmann, 1881) by Offenbach is based on the short stories of Ernst Hoffmann, who led a colourful life as artist and lawyer in Berlin in the 19th century. It relates three unhappy love affairs: the first, with Olympia, who turns out to be an automated doll; the second, with Giulietta, who is a courtesan; and the third, with Antonia, who is a gifted singer but in a frail state of health. From her mother she has inherited not only her beautiful voice but also a heart condition. This introduces the recently developed concept of heredity. Dr Miracle appears, allegedly to help Antonia with some medicine. He diagnoses cardiac arrhythmia; Antonia's pulse is fast and irregular. This is depicted musically by interrupted 16th notes (semiquavers; three each with a

A longer version of this article, including a full list of operas with doctors and their casts, is on bmj.com
Institute for Social Medicine,

Epidemiology and Health Economics, Charité University Medical Center,

Humboldt

University of Berlin,

Germany

Stefan N Willich

director

stefan.willich@

charite.de

BMJ 2006;333:1333-5 


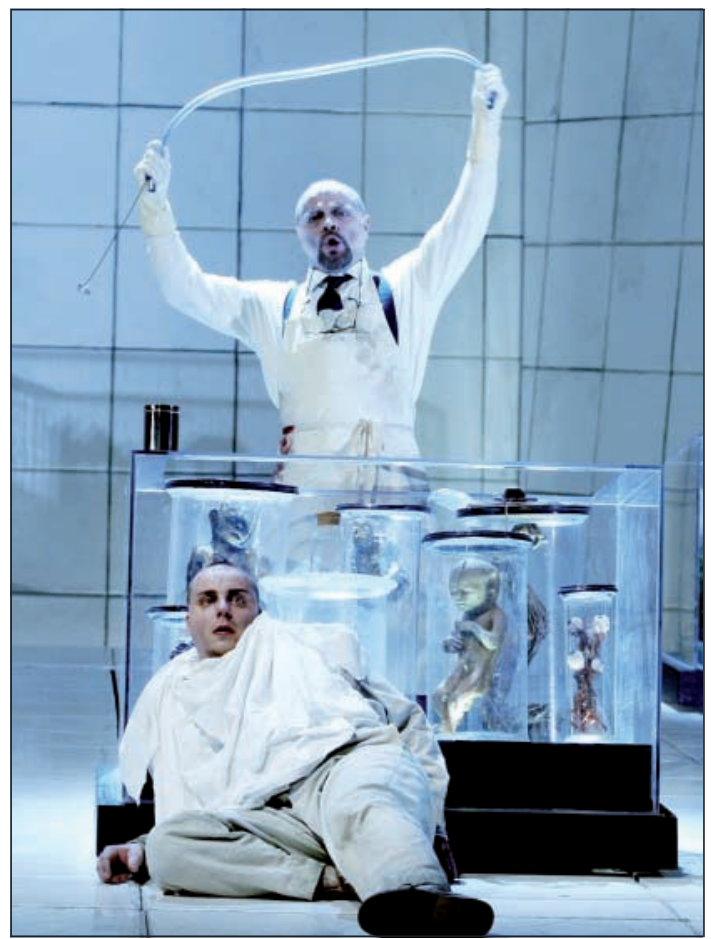

Doctor as researcher (Wozzeck)

rest) in the voice and orchestra. Descriptions of the musical rendition of the pulse as a rhythm dates as far back as the 4th century. ${ }^{7}$ Galen further developed the theories on the correlation between the quality of the pulse and musical rhythm, and a special notation on pulse characterisation was published in 1769 .

Dauber has elucidated the differential diagnosis of the hereditary causes of Antonia's arrhythmia. ${ }^{9}$ The clinical signs of mitral valve prolapse include fragility, occasional dyspnoea, anxiety, and exhaustion and occasional arrhythmias. Sudden cardiac death occurs rarely but has been reported. ${ }^{10}$ Antonia displays many of these described symptoms. Nevertheless, Dr Miracle asks her to sing, tempting her with the life of an artist that is much more exciting than a conventional life married to Hoffmann. ${ }^{11}$ Antonia sings and collapses on stage. The quickly summoned doctor arrives and pronounces her dead. Singing may thus have triggered the fatal arrhythmia. ${ }^{12}{ }^{13}$ Antonia's arrhythmia may be symbolic for something that has got out of rhythm. The three unhappy love affairs point towards a certain disorientation. If love is depicted here as subordinate to Antonia's slightly pessimistic or somewhat chaotic predisposition-particularly in connection with an exciting but strenuous life as an artist-the role of the doctor has to be connected with this scenario. The scientist not only fails to resolve the chaos or support the people involved but actually brings about the deadly consequence. $^{14}$

\section{Twentieth century}

The physicians reach a singing career peak in Alban Berg's Wozzeck (1925). Wozzeck is an uneducated and somewhat slow witted soldier working as a servant for the captain of his company. To earn some extra money he puts himself at the disposal of a doctor who uses him for medical experiments and as illustrative material for medical students. During a dietary experiment, Wozzeck is allowed to eat only legumes for one week and only meat for another. The doctor is shown here primarily as researcher focusing on scientific success. ${ }^{15}$ This becomes obvious when Wozzeck tells him about visual and acoustic hallucinations. The doctor's exalted and cynical reaction indicates his powerful position in relation to the humiliated patient-clearly a failed doctor-patient relationship. ${ }^{16}$ The opera ends tragically, Wozzeck kills his wife Marie and then commits suicide.

When Wozzeck was first performed in the mid-20s, debate among doctors in Germany was centring on the "crisis" in medicine. The rise in popularity of naturopathy was symbolic of a loss of public confidence in conventional medicine. Both doctors and lay people criticised the practice of human experiments without benefit to the patient as a method that served exclusively to further one's personal career. ${ }^{17}{ }^{18} \mathrm{In}$ Wozzeck, the negative portrayal of a scientist in the person of the doctor reflects the contemporary criticism of a physician who sacrifices the interests of the patient for the sake of his career. It also seems to forecast the dark role of medicine in the Nazi regime in Germany a decade later.

The psychiatric element plays an important part in several contemporary operas-for example, Wir Erreichen den Fluss (We Come to the River, 1976) by Hans Werner Henze. In the second part of the opera, the protagonist (a general) is a patient in a psychiatric clinic. Henze's opera was first performed in London, and the inclusion of the psychiatric element reflects the discussion on psychiatric care taking place at that time in Europe.

\section{Conclusions}

The doctor's function, importance, basis of knowledge, and social status clearly change over the history of opera (table). In the 18th century the doctor does not have a healing function but plays the buffoon in a socially subordinate and purely supportive role. This changes in the 19th century: initially he appears as a miracle doctor and charlatan but subsequently as a

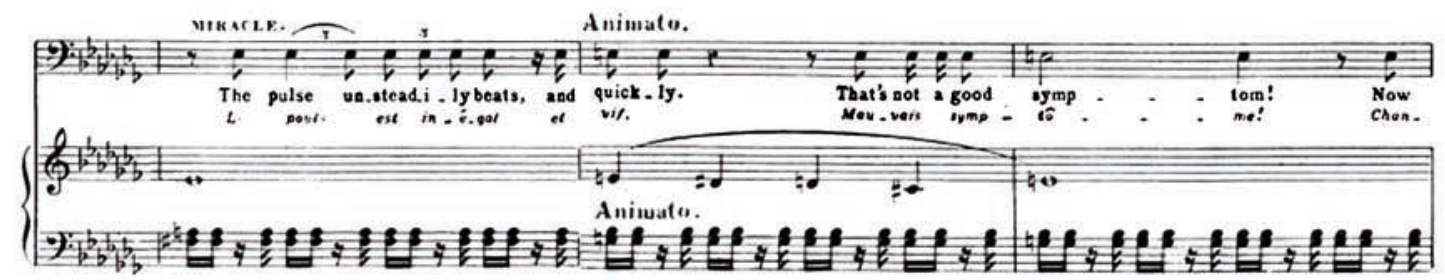

Dr Miracle identifies Antonia's arrhythmia (Tales of Hoffmann) 
The changing appearance of the physician in the history of opera

\begin{tabular}{|c|c|c|c|c|c|}
\hline Century & Role & Character & Role as physician & Basis of knowledge & Social position* \\
\hline 18th & Minor & Comic & None & Quackery & Inferior \\
\hline 19th & Minor and major & Comic/tragic & Clinical work & Magic potion/physical & Equal \\
\hline 20th & Major & Epic & Clinical work/research & Rational/biological & Superior \\
\hline
\end{tabular}

*In the context of the plot.

scientifically trained physician acting in a more sophisticated manner. The rise of competence, however, is paralleled by a rise in power with its potential to be used detrimentally. In the 20th century, the doctor often has a major role. He usually has high social standing, and, in addition to being a clinician, he is depicted as a researcher. The dynamics of the physician's role in the history of opera reflect the development of medicine and illustrate the development of the social position of doctors and the public attitude towards the medical profession over the past centuries.

Tonya Hongsermeier, Boston, and Peter Schmiedebach, Hamburg, provided valuable and insightful comments.

Competing interests: None declared.

1 Lederman RJ. Performing arts medicine. N Engl J Med 1989;320:246-8. 2 Sadie S, ed. The new Grove dictionary of opera. London: Maximilian Press, 1992.

3 Fielding JF. Myth, medicine and music. Irish J Med Sci 1990;159:77.

4 Baas HJ. Die geschichtliche Entwicklung des ärztlichen Standes und der medizinischen Wissenschaften. Berlin: F Wreden, 1986.

medizinischen Wissenschaften. Berlin: F Wreden, 1986.
Ober WB. Operatic “doctors." Practitioner 1976;216:110-6.

6 Goldovsky B. Some medical matters in operatic literature. Cleve Clin Q $1986 ; 53: 39-43$
7 Kümmel WF. Musik und Medizin. Freiburg/Munich: Karl Alber Verlag, 1977.

8 Bedford DE. The ancient art of feeling the pulse. Br Heart $J$ 1951;13:423-7.

9 Dauber LG. Death in opera: a case study, "Tales of Hoffmann"-Antonia. Am J Cardiol 1992;70:838-40.

10 Chesler E, King RA, Edwards JE. The myxomatous mitral valve and sudden death. Circulation 1983;67:632-9.

11 Malbeck ES. Ärzte, Krankheiten, Pharmaka. Die Verwendung medizinischer Elemente im italienischen, französischen und deutschen Opernlibretto des 19. Jahrhunderts [Dissertation]. Dusseldorf: University of Dusseldorf, 1971.

12 Boudalas H, Reynolds JC, Mazzaferri E, Wooley CF. Metabolic studies in mitral valve prolapse syndrome: a neuroendocrine-cardiovascular process. Circulation 1980;61:1200-5.

13 Willich SN, Maclure M, Mittleman M, Arntz HR, Muller JE. Sudden cardiac death. Support for a role of triggering in causation. Circulation 1993;87:1442-50.

14 Carmody J. Doctors and opera. Med J Austr 1991;155:783-4

15 Worth Estes J. The changing role of the physician in opera. Opera Quarterly 1994;10:143-55.

16 St Louis EK. The physician in contemporary opera: three divergent approaches to the doctor-patient relationship. Pharos 1992;55:15-20.

17 Klasen EM. Die Diskussion über eine "Krise" der Medizin in Deutschland zwischen 1925 und 1935 [Dissertation]. Mainz: University of Mainz, 1984.

18 Schmiedebach HP. Der wahre Arzt und das Wunder der Heilkunde. Erwin Lieks ärztlich-heilkundliche Ganzheitsideen. In: Abholz HH, Brocher T, Göbel E, eds. Der ganze Mensch und die Medizin. Hamburg: Argument-Verlag, 1989:33-53.

doi $10.1136 /$ bmj.39056.464074.55

\title{
Faints, fits, and fatalities from emotion in Shakespeare's characters: survey of the canon
}

\author{
Kenneth W Heaton
}

\section{Introduction}

The diseases mentioned in William Shakespeare's works have been much discussed, ${ }^{1-5}$ but another category of bodily change of medical interest seems to have escaped comment-the symptoms and signs induced by strong emotion in his characters. My interest in this topic was aroused when, studying Hamlet, I was struck by the violence of the hero's reaction to his encounter with his father's ghost on the battlements of Elsinore. Hamlet's anguished words, "Hold, hold, my heart, and you, my sinews, grow not instant old, but bear me stiffly up" (1.5.94; act, scene, line in Norton Shakespeare ${ }^{6}$ ), seem to suggest that his heart was palpitating and his knees were buckling. The symptoms suggest a near-syncopal attack or, conceivably, a paroxysmal tachycardia causing a drop in cardiac output. Continuing my studies of Shakespeare's plays and poems, I came across similar episodes, often involving actual loss of consciousness, and even several cases of sudden death, all occasioned by strong emotion. This prompted me to search systematically for bodily changes induced by emotion in the characters created by Shakespeare in his plays and long narrative poems. To put the findings in context, I examined in the same way some works by other playwrights active in the first half of Shakespeare's career.

\section{Methods}

Using a modern, annotated edition of the complete works of William Shakespeare, ${ }^{6}$ plus a monograph of Edward III, I read over a 20 month period every line of the 39 canonical plays and the three narrative poemsVenus and Adonis, The Rape of Lucrece, and A Lover's Complaint-mostly in chronological order, and systematically recorded every mention of a physical symptom or sign occurring in a character who was clearly experiencing strong emotion. Elsewhere, I have dubbed these phenomena "flags of feeling." ${ }^{\prime}$ They cover many systems of the body and, between them, attest to the playwright's acute awareness of the way the human body responds to emotion. Here I report the most dramatic of Shakespeare's flags of feeling: faints, fits, and death.

An extra table is on bmj.com 